\title{
PENERAPAN MANAJEMEN PENDIDIKAN MELALUI KEBIJAKAN SISTEM ZONASI PADA PENERIMAAN PESERTA DIDIK BARU DI SMAN 9 JENEPONTO
}

\author{
ST. SYARIFAH SYAHRI BANRIMANURUNG1, BAHARUDDIN ${ }^{2}$, MUHAMMAD \\ RUSMIN B. ${ }^{3}$ \\ 1SMA Negeri 9 Jeneponto, Indonesia, 2,3Universitas Islam Negeri Alauddin \\ Makassar, Indonesia \\ Email: 1Sya130988@gmail.com, 2baharuddinjepot@gmail.com, ํㅗusmin bersahaja@yahoo.co.id
}

\begin{abstract}
Implementation of Education Management through the Zoning System Policy on New Student Admissions at SMAN 9 Jeneponto

This study aims to describe the application of education management in the implementation of PPDB activities. The method used in this research is descriptive qualitative to describe the implementation of PPDB with a zoning system policy at SMAN 9 Jeneponto which is a superior school before the implementation of the zoning policy. The data sources used are primary data (words/actions from informants, namely school principals, PPDB committee, parents of students and students) and secondary data (PPDB data, photos and other related school documents). Data was collected by interview and documentation using research instruments, namely interview guidelines and document studies. The data collected was then analyzed by means of data reduction, data presentation and drawing conclusions. To ensure the truth of the data that has been collected, the researchers tested the validity of the data by extending observations, increasing persistence in careful and continuous observation, using reference materials and conducting member checks. The results of the study indicate that the implementation of PPDB is carried out based on the function of education management which consists of planning, organizing, implementing and evaluating. This can be seen from the process of PPDB activities that are structured and carried out systematically so that PPDB activities run well and obstacles that occur are overcome by carrying out coordination in accordance with the functions and duties of each PPDB committee. The implication of this research is that schools need to carry out socialization because there are still many parents of students who still consider SMAN 9 Jeneponto to be a superior school that can produce quality graduates even though the zoning policy has been in place for four years which has eliminated the title of favorite school.
\end{abstract}

Keywords: Education Management, PPDB, Zoning

\begin{abstract}
Abstrak: Penerapan Manajemen Pendidikan melalui Kebijakan Sistem Zonasi pada Penerimaan Peserta Didik Baru di SMAN 9 Jeneponto

Penelitian ini bertujuan untuk mendeskripsikan penerapan manajemen pendidikan pada pelaksanaan kegiatan PPDB. Metode yang digunakan pada penelitian ini adalah kualitatif deskriptif untuk menggambarkan pelaksanaan PPDB dengan kebijakan sistem zonasi di SMAN 9 Jeneponto yang merupakan sekolah unggulan sebelum penerapan kebijakan zonasi. Sumber data yang
\end{abstract}


digunakan adalah data primer (perkataan/tindakan dari informan yaitu kepala sekolah, panitia PPDB, orang tua peserta didik dan peserta didik) dan data sekunder (data PPDB, foto dan dokumen sekolah lainnya yang berkaitan). Pengumpulan data dilakukan dengan wawancara dan dokumentasi menggunakan instrumen penelitian yaitu pedoman wawancara dan studi dokumen. Data yang dikumpulkan kemudian dianalisis dengan cara reduksi data, penyajian data dan penarikan kesimpulan. Untuk meyakinkan kebenaran data yang telah dikumpulkan, maka peneliti melakukan uji keabsahan data dengan cara perpanjangan pengamatan, meningkatkan ketekunan pada pengamatan secara cermat dan berkesinambungan, menggunakan bahan referensi dan mengadakan member check. Hasil penelitian menunjukkan bahwa pelaksanaan PPDB dilakukan berdasarkan fungsi manajemen pendidikan yang terdiri dari perencanaan, pengorganisasian, pelaksanaan dan evaluasi. Hal ini terlihat dari proses kegiatan PPDB yang terstruktur dan terlaksana secara sistematis sehingga kegiatan PPDB berlangsung dengan baik dan kendala yang terjadi diatasi dengan melaksanakan koordinasi sesuai dengan fungsi dan tugas masing-masing panitia PPDB. Implikasi penelitian ini adalah sekolah perlu melakukan sosialisasi karena masih banyak orang tua peserta didik yang masih menganggap SMAN 9 Jeneponto adalah sekolah unggulan yang dapat menghasilkan lulusan yang berkualitas meskipun kebijakan zonasi sudah berlangsung selama empat tahun yang telah menghilangkan predikat sekolah favorit.

Kata Kunci: Manajemen Pendidikan, PPDB, Zonasi.

\section{PENDAHULUAN}

Kemajuan teknologi yang mengglobal saat ini telah berdampak terhadap berbagai aspek kehidupan baik di bidang ekonomi, politik, kebudayaan, seni, dan bahkan di dunia pendidikan (Rahman, 2021). Seiring dengan perkembangan zaman dan tuntutan pendidikan yang semakin kompleks menjadikan pemerintah terus berupaya membuat terobosan dengan menerbitkan berbagai macam kebijakan pendidikan guna meningkatkan kualitas sumber daya manusia di bidang pendidikan (Rohman, 2009). Menurut Undang-Undang No. 20 Tahun 2003 tentang Sistem Pendidikan Nasional harus mampu menjamin pemerataan kesempatan pendidikan. Peningkatan mutu serta relevansi dan efisiensi manajemen pendidikan untuk menghadapi tantangan sesuai tuntutan perubahan kehidupan lokal, nasional, dan global sehingga perlu dilakukan pembaruan pendidikan secara terencana, terarah, dan berkesinambungan.

Upaya yang dilakukan pemerintah dalam rangka mendorong peningkatan akses layanan pendidikan saat ini salah satunya adalah dengan melakukan pembenahan pada sistem Penerimaan Peserta Didik Baru atau disingkat dengan istilah PPDB yang banyak menuai permasalahan mulai dari berbagai kekeliruan seperti kurang efisiennya sistem yang dipakai, mekanisme yang tidak transparan, 
serta maraknya tindak kecurangan yang terjadi (Marini, 2019). Dengan demikian, perlu melakukan pembenahan pada pelaksanaan kegiatan PPDB dengan menerapkan pengelolaan yang baik dan sesuai dengan aturan untuk mengurangi permasalahan yang terjadi selain kebijakan PPDB yang memang masih terasa belum sempurna dirasakan manfaatnya di masyarakat utamanya tujuan untuk memeratakan kualitas pendidikan yang berkeadilan tanpa diskriminatif melalui pendekatan wilayah geospasial bernama zona (Direktorat Pembinaan SMA, 2019).

Permasalahan pendidikan terutama pada pelaksanaan rekrutmen peserta didik yang dilaksanakan setiap tahun sebagai upaya pemerintah untuk memperbaiki sistem pendidikan di Indonesia yang hingga saat ini masih selalu berusaha untuk memberikan yang terbaik bagi masa depan generasi penerus bangsa. Oleh karena itu, pemerintah saat ini mengeluarkan kebijakan baru pada kegiatan PPDB yang dikenal dengan kebijakan sistem zonasi.

Istilah "zonasi" mengacu pada Peraturan Menteri Pendidikan dan Kebudayaan Nomor 1 Tahun 2021 tentang Penerimaan Peserta Didik Baru pada Taman Kanak-kanak, Sekolah Dasar, Sekolah Menengah Pertama, Sekolah Menengah Atas dan Sekolah Menengah Kejuruan. Kegiatan PPDB merupakan kegiatan perekrutan peserta didik di awal tahun ajaran baru yang dilaksanakan setiap tahunnya. Kegiatan PPDB dengan sistem zonasi telah dilaksanakan dalam kurun waktu tahun 2017 hingga saat ini. Sejak tahun 2017, kegiatan penerimaan peserta didik baru di Sekolah Menengah Atas menggunakan sistem zonasi. Sistem ini mengharuskan peserta didik untuk mendaftar di sekolah sesuai dengan domisili masing-masing. Sehingga diharapkan peserta didik tidak lagi kesulitan mengakses pendidikan karena lokasi sekolah yang jauh, ataupun peserta didik tidak lagi dihadapkan pada permasalahan tidak diterima di "sekolah unggulan" karena semua sekolah yang ada adalah "sekolah unggulan". Hal tersebut berlandaskan pada pemerataan kualitas pendidikan di Indonesia.

Kebijakan sistem zonasi diharapkan mampu mengatasi segala kekurangan dalam sistem pendidikan di Indonesia. Namun sejak diterapkan, setiap tahun selalu menuai pro dan kontra bagi sekolah dan masyarakat. Pemerintah perlu melakukan perbaikan secara berkesinambungan terhadap semua komponen yang ada pada pendidikan. Tujuan pendidikan nasional dapat tercapai dengan disusunnya suatu strategi yang berkaitan dengan permasalahan-permasalahan pendidikan di Indonesia yang meliputi permasalahan mutu pendidikan, pemerataan pendidikan dan manajemen pendidikan. Oleh karena itu, sistem zonasi diharapkan mampu mengatasi hal tersebut. Selain itu pada tahap pelaksanaan kegiatan perlunya menerapkan manajemen yang baik agar kegiatan PPDB berjalan dengan sempurna meskipun dari segi kebijakan masih belum dirasakan manfaatnya secara baik. 
St. Syarifah Syahri Banrimanurung, Baharuddin, Muhammad Rusmin B.

Perubahan pada sistem perekrutan peserta didik di tingkat sekolah menengah atas membawa dampak, baik secara langsung maupun tidak langsung kepada semua pihak yang berkepentingan baik itu sekolah, peserta didik, orang tua peserta didik serta pemerintah. Salah satu perubahan yang dirasakan adalah sistem perekrutan yang dahulu dilakukan secara offline dan saat ini dilaksanakan secara online, dahulu memperhatikan nilai hasil ujian nasional saat ini hanya berdasarkan zonasi, dahulu dapat memilih sekolah berdasarkan mutunya saat ini semua sekolah dianggap memiliki mutu yang sama.

Kebijakan sistem zonasi pada perekrutan peserta didik yang berdasarkan domisili dengan harapan bahwa semua dapat mengakses layanan pendidikan yang sama bermutu di setiap wilayah nyatanya di lapangan adalah masih adanya orang tua peserta didik yang menganggap telah dirugikan dengan adanya peraturan ini, terutama peserta didik yang berprestasi karena sistem zonasi mengutamakan jarak rumah dan tidak mengutamakan nilai hasil ujian nasional. Kelompok masyarakat ini menganggap bahwa sekolah yang tidak sesuai dengan keinginannya tidak dapat mengakomodir prestasi akademiknya kelak sehingga akan berdampak pada prestasi peserta didik.

Saat ini, masih ada beberapa kelompok masyarakat yang melakukan manipulasi agar dapat masuk pada sekolah yang dianggap favorit. Hal ini menunjukkan bahwa selama empat tahun kebijakan zonasi berjalan masyarakat belum merasa terjadi pemerataan mutu layanan pendidikan seperti yang selalu digaungkan oleh pemerintah. Setelah empat tahun berjalan belum diketahui secara pasti apakah penerapan sistem zonasi di kabupaten Jeneponto berdampak baik bagi peserta didik dan sekolah dalam hal pemerataan kualitas karena beberapa masyarakat didapati melakukan perubahan pada alamat di kartu keluarganya serta membuat surat keterangan miskin untuk dapat masuk ke sekolah favorit melalui jalur lain.

Sekolah yang masih dianggap favorit di kabupaten Jeneponto salah satunya adalah SMAN 9 Jeneponto yang dahulu bernama SMAN Khusus Jeneponto yang merupakan sekolah unggulan. SMAN 9 Jeneponto merupakan salah satu sekolah yang paling favorit dan banyak di kejar oleh peserta didik untuk melanjutkan sekolah di tingkat atas di bandingkan dengan sekolah lainnya disebabkan banyak prestasi yang pernah di ukir di antaranya bidang akademik, prestasi olahraga dan prestasi lainnya baik secara individu maupun secara berkelompok oleh peserta didiknya. Sekolah tersebut terletak di pusat kota kabupaten Jeneponto.

Penerimaan peserta didik baru disempurnakan di tahun 2021 melalui Permendikbud Nomor 1 Tahun 2021, membuat banyak perubahan di SMAN 9 Jeneponto. Salah satu dampak yang terjadi adalah penyesuaian pola pembelajaran. Para guru di SMAN 9 Jeneponto ditantang menunjukkan kemampuannya dalam 
mendidik agar mencapai outcome peserta didik sesuai harapan yang telah dihasilkan sekolah ini sebelumnya. Kenyataan didapatkan bahwa penggunaan sistem zonasi tidak memberikan kenyamanan baik orang tua atau wali murid untuk menyekolahkan anaknya karena tidak sesuai dengan kriteria anaknya. Tuntutan sekolah yang dirasa berat bagi peserta didik yang kurang dalam hal kemampuan akademiknya pastinya akan mengalami kesulitan beradaptasi di sekolah yang mengakibatkan ketidaknyamanan peserta didik yang berimbas pada nilai akademiknya. Sebaliknya siswa dengan kemampuan akademik yang baik tidak dapat bersekolah sesuai keinginannya karena skor jarak rumah dari sekolah yang kurang mengakibatkan peserta didik berada dalam lingkungan sekolah yang tidak mendukung kemampuan belajarnya seperti ketersediaan sarana prasarana serta tenaga pendidik yang kurang memadai yang berakibat pada nilai akademiknya yang kurang maksimal.

Kemudahan pada penerimaan peserta didik baru dalam mengakses layanan pendidikan nyatanya tidak dirasakan oleh beberapa kelompok masyarakat. Permasalahan yang ada diantaranya adalah penggunaan aplikasi yang dilakukan secara daring dikarenakan diakses oleh ratusan orang secara bersamaan membuat kemampuan server mengalami down/ kesulitan dalam mengakses link pendaftaran di laman yang telah disediakan, belum lagi karena permasalahan jaringan. Orang tua/wali peserta didik sebelumnya harus membuat akun pendaftaran, mengisi form dan sebagainya yang dimana sebagian kelompok masyarakat merasa keluitan sehingga membandingkan dengan perekrutan secara luring yang dianggap lebih mudah karena hanya mendatangi sekolah saja tanpa perlu melakukan akses link pendaftaran yang terkadang error. Untuk mengatasi hal tersebut, perlu memperhatikan pelaksanaan kegiatan PPDB dengan menerapkan manajemen/ pengelolaan pelaksanaan kegiatan secara benar. Hal ini untuk mengurangi permasalahan pelaksanaan PPDB yang mulai dari kebijakannya yang sudah menimbulkan banyak masalah walaupun sudah berjalan selama 5 (lima) tahun.

Kebijakan pendidikan sistem zonasi setiap tahun dilakukan perubahan melalui Permendikbud menunjukkan bahwa terdapat permasalahan serius yang perlu dilakukan evaluasi pada kebijakan tersebut. Belum lagi pada permasalahan dampak yang ditimbulkan dari kebijakan ini apakah memiliki manfaat atau justru malah membuat banyak kerugian pada peserta didik dan sekolah khususnya di sekolah yang berlabel favorit/unggul yang sebelum diberlakukan kebijakan system zonasi selalu menghasilkan lulusan yang berkualitas yang ujung-ujungnya dapat memberikan kontribusi yang baik pada Negara khususnya pada penciptaan sumber daya manusia yang berkualitas. 
St. Syarifah Syahri Banrimanurung, Baharuddin, Muhammad Rusmin B.

Banyaknya permasalahan yang timbul mulai dari kebijakan dan sistem perekrutan peserta didik baru serta dampak yang ditimbulkan dari penerapan kebijakan ini membuat peneliti tertarik untuk menyoroti manajemen perekrutan peserta didik berdasarkan teknik penerapan manajemen pendidikan melalui penelitian yang berjudul "Penerapan Manajemen Pendidikan Kebijakan Sistem Zonasi pada Penerimaan Peserta Didik Baru di SMAN 9 Jeneponto".

Tujuan penelitian ini adalah untuk mendeskripsikan penerapan manajemen pendidikan sistem zonasi pada penerimaan peserta didik baru di SMAN 9 Jeneponto, untuk mendeskripsikan kebijakan pendidikan sistem zonasi pada penerimaan peserta didik baru di SMAN 9 Jeneponto dan untuk mendeskripsikan dampak penerapan kebijakan pendidikan sistem zonasi di SMAN 9 Jeneponto.

\section{METODE PENELITIAN}

Penelitian ini merupakan jenis penelitian kualitatif yang bertujuan untuk membuat pengumpulan data secara sistematis, faktual, dan akurat (Suryabrata, 2013) mengenai fakta-fakta pelaksanaan PPDB zonasi di SMAN 9 Jeneponto. Penelitian ini menggunakan pendekatan analisis deskriptif yang dilakukan terfokus pada pelaksanaan kegiatan PPDB untuk diamati dan dianalisis secara cermat proses pelaksanaannya yang kerap menimbulkan permasalahan. Penelitian ini bertujuan memahami suatu fenomena dalam konteks sosial secara alamiah dengan mengedepankan proses interaksi komunikasi yang mendalam antara peneliti dengan fenomena yang diteliti (Herdiansyah, 2012).

Waktu penelitian akan dilaksanakan pada bulan Juli 2021 sampai dengan September 2021 yang merupakan waktu selesainya pelaksanaan PPDB di SMAN 9 Jeneponto. Waktu ini sesuai untuk pengambilan data serta pelaksanaan wawancara karena kegiatan PPDB sudah rampung pelaksanaannya. Sumber data primer dalam penelitian ini merupakan semua perkataan yang penting atau tindakan dari informan yaitu pejabat dinas yang menangani PPDB, peserta didik baru, orang tua peserta didik baru, guru, karyawan, serta stakeholders dalam pelaksanaan Penerimaan Peserta Didik Baru (PPDB) online dengan sistem zonasi. Selain dari semua itu merupakan sumber data sekunder, di antaranya dokumentasi berupa data tertulis, foto dan data statistik yang diperoleh dari pihak-pihak terkait.

Fokus penelitian pada dasarnya adalah masalah yang bersumber pada pengalaman peneliti atau melalui pengetahuan yang diperoleh melalui keputusan ilmiah ataupun kepustakaan lainnya (Moleong, 2005). Adapun fokus dalam penelitian ini berpusat pada penerapan manajemen pendidikan sistem zonasi pada penerimaan peserta didik baru di SMAN 9 Jeneponto. Pada tahap ini peneliti menggunakan teori dari Henry Fayol, Luther M. Gullich dan John R. Beisline pakar 
ilmu manajemen yang mengemukakan tentang fungsi manajemen pendidikan yaitu perencanaan, pengorganisasian, pelaksanaan dan evaluasi (Hikmat, 2009).

Dalam penelitian kualitatif ini, peneliti bertindak sebagai instrumen penelitian, sekaligus merupakan perencana pengumpulan data, analisis, penafsir data, dan pada akhirnya peneliti menjadi pelopor hasil penelitiannya (Moleong, 2005). Ada dua macam teknik pengumpulan data yang digunakan dalam penelitian ini, yaitu wawancara dilakukan dengan tanya jawab langsung dengan subyek penelitian maupun informan lainnya untuk memperoleh informasi atau data secara lebih jelas dan mendalam. Dengan digunakannya interview ini peneliti akan dapat menggali apa yang diketahui dan dialami oleh seseorang yang diteliti, juga apa yang tersembunyi di dalam diri objek penelitian. Di samping itu apa yang ditanyakan kepada informan bisa mencakup hal-hal yang bersifat lintas waktu berkaitan dengan masa lampau, masa sekarang dan juga masa yang akan datang. Selanjutnya adalah dokumentasi yaitu teknik pengumpulan data sekunder dengan cara mencari data dari sejumlah dokumen instansi yang dianggap penting dan mempunyai relevansi dengan masalah yang diteliti.

Instrumen penelitian yang digunakan oleh peneliti dalam melaksanakan penelitian dengan menggunakan suatu metode guna memperoleh hasil pengamatan dan data yang diinginkan. Dalam penelitian ini peneliti memilih menggunakan instrumen pedoman wawancara dan studi dokumen. Teknik pengecekan keabsahan data yang sesuai yaitu dengan teknik yang terdiri dari perpanjangan pengamatan, meningkatkan, melakukan member check (Sugiyono, 2016).

Langkah-langkah dalam analisis data pada penelitian ini adalah reduksi data dengan merangkum, memilih hal-hal yang pokok, memfokuskan pada hal-hal yang penting, dicari tema dan polanya dan membuang yang tidak perlu. Dengan demikian data yang telah direduksi akan memberikan gambaran yang lebih jelas, dan mempermudah peneliti untuk melakukan pengumpulan data selanjutnya, dan mencarinya bila diperlukan. Penyajian data dilakukan dalam bentuk uraian singkat, bagan, hubungan antar kategori, dan sejenisnya. Metode analisis data yang digunakan dalam penelitian ini adalah penelitian deskriptif kualitatif.

\section{HASIL DAN PEMBAHASAN}

Hasil penelitian penerapan manajemen pendidikan sistem zonasi pada penerimaan peserta didik baru di SMAN 9 Jeneponto disajikan mulai dari perencanaan, pengorganisasian, pelaksanaan dan evaluasi. Data tersebut diperoleh dari wawancara dan dokumentasi berupa data-data yang diambil di lokasi penelitian. 
St. Syarifah Syahri Banrimanurung, Baharuddin, Muhammad Rusmin B.

\section{Perencanaan Peserta Didik Baru}

Perencanaan penerimaan peserta didik baru dilakukan setiap awal tahun ajaran baru dari masuk hingga lulus. perencanaan peserta didik adalah suatu aktivitas memikirkan di muka tentang hal-hal yang harus dilakukan berkenaan dengan peserta didik di sekolah, baik sejak peserta didik akan memasuki sekolah maupun mereka akan lulus dari sekolah. Perencanaan penerimaan peserta didik baru memuat antara lain analisa kebutuhan peserta didik, rekrutmen peserta didik, jadwal PPDB, bagaimana seleksi peserta didik, penempatan peserta didik, penambahan nilai piagam, pencatatan dan pelaporan. Perencanaan terhadap peserta didik menyangkut perencanaan siswa baru, kelulusan, jumlah putus sekolah dan kepindahan (Hakim \& Mukhtar, 2018). Hal-hal yang direncanakan dalam penerimaan peserta didik baru berbasis online terlampir sesuai dengan petunjuk teknis dan petunjuk pelaksanaan pedoman pelaksanaan penerimaan peserta didik baru tahun ajaran 2021/2022 berdasarkan keputusan Dinas Pendidikan Provinsi Sulawesi Selatan memuat komponen.

Bustari \& Rahmawati (2015)mengemukakan bahwa penerimaan peserta didik baru merupakan kegiatan yang sangat penting karena keberhasilan pendidikan sangat dipengaruhi oleh kegiatan perencanaan ini. Penentuan tujuan sistem PPDB zonasi jenjang SMA berpedoman pada buku petunjuk teknis dan pedoman pelaksanaan Penerimaan Peserta Didik Baru tahun 2021 sebagai berikut obyektivitas, artinya bahwa penerimaan peserta didik harus memenuhi ketentuan. Transparansi, artinya pelaksanaan penerimaan peserta didik bersifat terbuka dan dapat diketahui masyarakat termasuk orang tua peserta didik, untuk menghindari penyimpangan-penyimpangan yang mungkin terjadi. Akuntabilitas, artinya penerimaan peserta didik dapat dipertanggungjawabkan kepada masyarakat baik menyangkut prosedur maupun hasilnya. Tidak diskriminatif, artinya setiap warga Negara yang berusia sekolah dapat mengikuti program pendidikan di wilayah Negara Kesatuan Republik Indonesia tanpa membedakan daerah asal, agama dan golongan. Penetapan persyaratan peserta didik baru Berdasarkan Surat Keputusan Bersama Kepala Dinas Pendidikan. Telah lulus dan memiliki ijazah SMP/MTs/SMPLB/Program Paket B atau satuan pendidikan yang sederajat dan memiliki SKHUN/STL Program Paket B atau satuan pendidikan yang sederajat. Berusia setinggi-tingginya 21 tahun pada tanggal 1 Juli 2021, kecuali dari SMPLB. Jumlah peserta didik pada SMA/MA dalam setiap rombongan belajar/kelas maksimum 34 orang. Menentukan jadwal penerimaan peserta didik baru.

Tahapan penyusunan jadwal penerimaan peserta didik baru sebelumnya disesuaikan dengan bulan saat tahun ajaran baru berlangsung. kegiatan secara urut, kapan dilaksanakan, siapa yang bertanggungjawab melaksanakan, dan dimana kegiatan harus dilaksanakan. Komponen penjadwalan dalam penerimaan 
peserta didik baru antara lain jadwal pendaftaran, tes khusus, analisis penyusunan peringkat, pengumuman, pendaftaran ulang, dan jadwal hari pertama calon peserta didik yang diterima masuk sekolah. Jadwal PPDB online tersebut termuat di situs website.

Rencana kerja panitia seleksi PPDB tahun 2021/2022 antara pihak dinas dan pihak sekolah masing-masing membentuk struktur kepanitian PPDB sendirisendiri. Tim panitia penyelenggara ditentukan pada tahap perencanaan dengan menyusun tugas dan kewenangan setiap panitia PPDB online. Panitia PPDB online pihak dinas yang terlibat ialah Kepala Dinas, Bidang Pendidikan Menengah dan Sub Bagian Perencanaan dan Pelaporan.

Struktur panitia PPDB online pihak sekolah ialah penanggung jawab, ketua, sekretaris, bendahara, humas dan anggota. Panitia PPDB pihak dinas dan sekolah terkait PPDB online, ada koordinasi yang dilakukan melalui website antara operator dinas dan operator sekolah saat proses penerimaan peserta didik baru berlangsung. e. Sistem Seleksi PPDB Sistem penerimaan peserta didik adalah cara penerimaan peserta didik baru (Imron, 2011). Ketua PPDB mengemukakan bahwa sistem berdasarkan pada sistem secara komputerisasi jadi secara otomatis sudah dirancang dalam hal perankingan jarak rumah terdekat. Hal ini dampaknya lebih efektif dan efisien serta mempermudah informasi bagi calon siswa, orang tua dan masyarakat.

Anggaran Penyelenggaraan PPDB menggunakan dana Bantuan Operasional Sekolah (BOS) sehingga tidak ada pungutan biaya apapun. Berdasarkan petunjuk teknis Sekolah menetapkan daya tampung, besaran kuota dan wilayah zonasi (titik koordinat) sebelum pelaksanaan kegiatan PPDB sesuai dengan ketentuan yang ditentukan oleh Dinas Pendidikan.

\section{Pengorganisasian Penerimaan Peserta Didik Baru}

Pengorganisasian bertujuan untuk membagi pekerjaan kepada setiap orang yang ada di lembaga sesuai dengan kemampuannya serta mengoordinasikannya dalam rangka mencapai tujuan organisasi. mengorganisasikan adalah memilih tugas-tugas yang harus dikerjakan, siapa yang mengerjakan, bagaimana tugas itu dikelompokkan, siapa yang melapor, kapan dan di mana keputusan dibuat (Imron, 2011). Penerimaan peserta didik baru berbasis online ini bersifat sentral artinya kewenangan penuh ada di dinas. Tugas operasional panitia PPDB di Dinas Pendidikan terdiri dari penanggung jawab, ketua I, ketua II, sekretaris dan anggota. Personil yang termasuk dalam panitia PPDB adalah pegawai Dinas Pendidikan. Panitia dalam penerimaan peserta didik baru berbasis online ini melibatkan kerja sama dengan PT. Telkom selaku provider untuk membantu dalam mengelola IT. Oleh karena itu, PT. Telkom juga termasuk dalam panitia PPDB namun hanya 
sebagai tim penunjang PPDB online. Sedangkan untuk kepanitiaan PPDB sekolah terdiri dari penanggung jawab, ketua, sekretaris, bendahara, humas dan anggota. Personil yang termasuk didalamnya ialah komposisi gabungan antara kepala sekolah, guru, dan tenaga kependidikan. Hal ini sesuai dengan pendapat Hakim \& Mukhtar (2018) menyatakan bahwa panitia penerimaan peserta didik meliputi semua unsur guru, tenaga TU dan dewan sekolah/komite sekolah.

Panitia PPDB memiliki tugas pokok dan fungsi masing-masing sesuai dengan jabatan yang dimiliki. bahwa panitia penerimaan peserta didik baru mempunyai tugas yaitu menyusun petunjuk teknis tentang penerimaan peserta didik baru, mensosialisasikan petunjuk teknis kepada sekolah/UPTD, memfasilitasi/melatih operator sekolah dalam penerapan penerimaan peserta didik baru online, memantau pelaksanaan kegiatan, mengevaluasi pelaksanaan kegiatan, menyusun laporan pelaksanaan kegiatan penerimaan peserta didik baru.

Deskripsi tugas panitia PPDB setiap sekolah SMA Negeri dibuat berdasarkan keputusan dari setiap Kepala SMAN 9 Jeneponto dengan tetap mengacu pada SK Nomor 421.3/199/UPT-SMA.9/JNP/DISDIK tentang Pembentukan Panitia PPDB Online Tahun Pelajaran 2021/2022 Panitia pihak dinas dan pihak sekolah berkoordinasi terkait sosialisasi petunjuk teknis pelaksanaan PPDB online dan proses entri data yang dilakukan operator dinas dan operator sekolah saat PPDB berlangsung.

\section{Pelaksanaan Penerimaan Peserta Didik Baru}

Pelaksanaan penerimaan peserta didik baru berbasis online ini merupakan implementasi perencanaan PPDB. Setiap kegiatan pelaksanaan merupakan hal pokok yang menunjang keberhasilan tujuan yang akan dicapai setiap kegiatan. Pelaksanaan/ penggerakan sebagai keseluruhan usaha, cara, teknik dan metode untuk mendorong para anggota organisasi agar mau dan ikhlas untuk bekerja dengan sebaik-baiknya demi tercapainya tujuan secara efektif dan efisien. Tahap pelaksanaan PPDB online ini berlangsung atas kerjasama antara operator dinas dan operator sekolah. Operator sekolah melakukan entri data calon siswa baru yang hendak melakukan pendaftaran PPDB di setiap sekolah. Setelah itu data tentang siswa baru tersebut dikirim kepada operator dinas melalui website. Sarana penunjang dalam PPDB online ialah website http://sulsel.siapku_ppdb.com yang terdapat informasi terkait PPDB dan calon siswa baru dapat melihat hasil seleksi melalui situs ini. Informasi yang disajikan dalam web dapat memudahkan dalam pencarian segala macam informasi yang dibutuhkan berupa teks, gambar, audio visual, model grafis, dan lain-lain.

Kewenangan penuh ada pada operator dinas yang melakukan seleksi calon

peserta didik baru dengan memasukkan NUN (Nilai Ujian Nasional), meranking 
melalui sistem, dan tambahan nilai piagam. Hakim \& Mukhtar, (2018) mengemukakan bahwa cara seleksi peserta didik adalah melalui tes atau ujian, melalui penelusuran bakat kemampuan biasanya prestasi, melalui nilai ujian akhir. Seleksi peserta didik pada dasarnya adalah kegiatan pemilihan calon peserta didik bahwa seleksi peserta didik merupakan kegiatan pemilihan calon peserta didik untuk menentukan diterima atau tidaknya calon peserta didik menjadi peserta didik di lembaga pendidikan sesuai dengan ketentuan berlaku.

Tahap pelaksanaan penerimaan peserta didik baru berbasis online dilakukan sesuai dengan skema dan alur pelaksanaan PPDB online SMA Negeri yang diatur dalam SK Gubernur Provinsi Sulawesi Selatan Nomor 1119/IV/TAHUN 2021 DAN Petunjuk Teknis PPDB 2021 Pedoman Penerimaan Peserta Didik Baru (PPDB) BAB $\mathrm{V}$ Pasal 5 tentang tata cara pendaftaran peserta didik baru dengan sistem online yaitu calon peserta didik mendaftar pada sekolah yang menyelenggarakan PPDB online sesuai dengan jenjangnya dengan mengunggah dokumen berupa SKHUN asli/ surat keterangan tentang Nilai Ujian Nasional dari sekolah, foto copy ijazah setingkat di bawahnya dan pas foto $3 \times 4$ sebanyak 3 lembar, melampirkan fotocopy (dilegalisir). Salah satu bukti prestasi bidang akademis/olahraga/kesenian/ keterampilan atau bidang lainnya bagi yang memiliki, calon peserta didik menyerahkan berkas pendaftaran untuk dilakukan verifikasi oleh panitia. Calon peserta didik dapat memilih 2 pilihan sekolah negeri, entri data dilakukan oleh operator sekolah berdasarkan formulir pendaftaran. Calon peserta didik menunggu pengesahan tanda bukti pendaftaran/formulir pendaftaran dari panitia pendaftaran yang akan digunakan sebagai bukti pada pendaftaran ulang apabila diterima. Tanda bukti pendaftaran disimpan calon peserta didik dan akan digunakan sebagai tanda bukti daftar ulang apabila diterima dan tanda bukti untuk mengambil berkas apabila tidak diterima. Jurnal harian dan pengumuman hasil PPDB online dapat diakses lewat internet atau dapat dilihat langsung pada pengumuman di sekolah yang bersangkutan.

Pendaftaran calon peserta didik diutamakan bagi peserta didik/siswa yang berasal dari Kabupaten Jeneponto, penerimaan peserta didik baru yang berasal dari luar Kabupaten maksimum 10\% dari daya tampung sekolah, kecuali daerah perbatasan dapat dipertimbangkan untuk memenuhi daya tampungnya. Apabila terdapat pendaftar dengan peringkat yang sama pada batas yang akan diterima, maka menggunakan parameter yaitu skala prioritas pilihan calon peserta didik. Calon peserta didik lulusan dalam daerah Kabupaten Jeneponto lebih diprioritaskan, perbandingan nilai mata pelajaran UN dengan urutan Matematika, Bahasa Indonesia, Bahasa Inggris. 
St. Syarifah Syahri Banrimanurung, Baharuddin, Muhammad Rusmin B.

\section{Evaluasi Penerimaan Peserta Didik Baru}

Evaluasi merupakan tahapan yang digunakan untuk mengetahui tingkat ketercapaian tujuan program dan apabila belum tercapai maka dapat diketahui letak kekurangan yang nantinya dijadikan sebagai bahan koreksi. Hal ini menjelaskan pengawasan/evaluasi merupakan suatu proses untuk menerapkan pekerjaan apa yang sudah dilaksanakan, menilainya dan bila perlu mengoreksi dengan maksud supaya pelaksanaan sesuai dengan rencana semula (Manullang, 2018). Berdasarkan hal tersebut evaluasi penerimaan peserta didik baru dilakukan oleh pihak dinas melalui pengawasan antara operator dinas dan operator sekolah di website PPDB Sul-Sel saat proses pelaksanaan entri data calon siswa baru berlangsung dan mengevaluasi hasil laporan PPDB dari pihak sekolah yang memuat rencana siswa yang diterima/daya tampung tiap sekolah, jumlah pendaftar, dan siswa yang diterima. Berdasarkan hasil laporan terkait kekurangan siswa, dinas memberi kewenangan pihak sekolah melakukan PPDB secara manual. Tindak lanjut dari evaluasi adalah penyempurnaan juknis PPDB terkait ketentuan nilai piagam dan pihak dinas mengedarkan kuesioner yang wajib diisi setiap SMA Negeri untuk mengetahui kendala yang terjadi di sekolah.

Monitoring dilakukan oleh kepala Cabang Dinas Pendidikan Wilayah VII Jeneponto-Takalar dan Kepala MKPS kabupaten Jeneponto untuk menyaksikan tahapan pelaksanaan PPDB secara daring, memastikan sisa kuota yang tersedia di SMAN 9 Jeneponto untuk diberikan kepada calon peserta didik yang belum mendapatkan akses layanan pendidikan. Setiap melaksanakan program kerja atau kegiatan perlu diadakan evaluasi karena hakikat evaluasi program ialah pelaksana ingin mengetahui tingkat ketercapaian tujuan program dan apabila tujuan belum tercapai sebagaimana ditentukan, pelaksana mengetahui letak kekurangan dan penyebabnya. Saat penerimaan peserta didik baru terdapat tahap evaluasi yang dilakukan oleh pihak dinas. Hal ini dikemukakan oleh Ketua PPDB sebagai berikut:

"Karena PPDB tahun 2021/2022 dilakukan secara daring, maka evaluasi yang dilakukan pihak dinas berupa pengawasan yang dilakukan oleh operator dinas melalui website PPDB dan semua berjalan dengan baik, kami menerima hasil proses PPDB dari tiap sekolah. Untuk data hasil rekapitulasi laporan PPDB dilakukan melalui sistem website secara tidak langsung dapat dilihat oleh calon siswa dan masyarakat.

Berkaitan dengan jaringan yang tiba-tiba error di hari pertama pendaftaran telah kami koordinasikan dan segera ditindaklanjuti oleh pihak Dinas Pendidikan Provinsi Sulawesi Selatan melalui surat nomor 004.5/5081-Sekret.2/Disdik maka kami memberikan perpanjangan waktu pendaftaran. Dan untuk kekurangan murid berdasarkan laporan PPDB sekolah, kami diberikan kewenangan untuk melakukan penerimaan peserta didik sebanyak 14 kuota yang masuk pada jalur pendaftaran 
prestasi akademik. Dari hasil penelitian di atas dapat disimpulkan bahwa kegiatan PPDB di SMAN 9 Jeneponto dilaksanakan secara sistematis sesuai dengan fungsi manajemen pendidikan.

\section{PENUTUP}

Berdasarkan hasil penelitian yang dilakukan disimpulkan bahwa penerapan manajemen pendidikan pada pelaksanaan PPDB melalui kebijakan sistem zonasi telah dilaksanakan sesuai dengan fungsi manajemen pendidikan yang terdiri dari perencanaan dimulai dengan penentuan tujuan yaitu menetapkan wilayah zonasi penetapan persyaratan PPDB berdasarkan petunjuk teknis, penentuan jadwal, rencana kerja panitia, pengalokasian dana kegiatan dan penetapan daya tampung. Pengorganisasian yaitu membentuk panitia PPDB, pemberian tugas, tanggung jawab dan wewenang. Pelaksanaan PPDB sesuai dengan tata cara pendaftaran yang telah disusun oleh tim panitia PPDB dengan waktu yang telah ditentukan berdasarkan jenis jalur pendaftaran. Evaluasi kegiatan PPDB untuk melihat tingkat ketercapaian tujuan program, terlihat dari jumlah kuota yang direncanakan dan yang terpenuhi dari setiap jalur pendaftaran dijadikan acuan untuk pelaksanaan PPDB di tahun berikutnya.

Implikasi penelitian ini adalah sekolah diharapkan melakukan sosialisasi secara lebih intensif kepada masyarakat untuk mengurangi kontra yang terjadi akibat pelaksanaan kebijakan zonasi yang belum diterima dengan baik. Perlunya dilakukan penelitian lebih lanjut terhadap permasalahan yang kerap terjadi pada pelaksanaan PPDB ditinjau dari kesesuaian kebijakan pada wilayah pelaksana.

\section{DAFTAR PUSTAKA}

Bustari, M., \& Rahmawati, T. (2015). Manajemen Peserta Didik. Yogyakarta: UNY Press.

Hakim, L., \& Mukhtar. (2018). Dasar-dasar Manajemen Pendidikan. Jambi: Timur Laut Aksara.

Herdiansyah, H. (2012). Metodologi Penelitian Kualitatif untuk Ilmu-ilmu Sosial. Jakarta: Salemba Humanika.

Hikmat. (2009). Manajemen Pendidikan. Bandung: Pustaka Setia.

Imron, A. (2011). Manajemen Peserta Didik Berbasis Sekolah. Jakarta: Bumi Aksara.

Manullang, M. (2018). Dasar-Dasar Manajemen. Yogyakarta: Gadjah Mada.

Marini, K. (2019). Implementasi Kebijakan Sistem Zonasi dalam Penerimaan Peserta Didik Baru pada SMA Negeri di Kota Bandang Lampung. Lampung: Universitas Bandar Lampung.

Moleong, L. J. (2005). Metodologi Penelitian Kualitatif. Bandung: Remaja Rosdakarya. 
St. Syarifah Syahri Banrimanurung, Baharuddin, Muhammad Rusmin B.

Rahman, D. (2021). Pemanfaatan Internet Sebagai Sumber Belajar dan Informasi. Jurnal Perpustakaan Dan Informasi, 1(1), 9-14.

Rohman, A. (2009). Memahami Pendidikan dan Ilmu Pendidikan. Yogyakarta: Laksbang Mediatama.

SMA, D. P. (2019). Zonasi Pendidikan Membangun Inspirasi tanpa Diskriminasi. Jakarta: Kementerian Pendidikan dan Kebudayaan.

Sugiyono. (2016). Metode Penelitian Kuantitatif, Kualitatif, dan R\&D. Bandung: Alfabeta.

Suryabrata, S. (2013). Metodologi Penelitian. Jakarta: Raja Grafindo Persada. 